\title{
A Rare Complication Caused by Dry Needling Method: Tension Pneumothorax
}

\section{Kuru İğneleme Metodunun Neden Olduğu Nadir Bir Komplikasyon: Tansiyon Pnömotoraks}

Nalan Kozacı' ', Nilay Çavuşoğlu Yalçın², Muharrem Özkaya², Vedat Kırpat ${ }^{1}$, Ahmet Çelik'

\begin{abstract}
Tension pneumothorax, resulting in deterioration of cardiopulmonary function due to displacement of the mediastinal structures, is a fatal condition without early diagnosis and treatment. This article is a description of the case of a patient who developed iatrogenic bilateral pneumothorax and subsequent tension pneumothorax due to dry needling used in the treatment of myofascial pain.
\end{abstract}

Key words: Myofascial pain, dry needling, tension pneumothorax.

\section{Özet}

Tansiyon pnömotoraks mediastinal yapıların yer değiştirmesine bağlı kardiyopulmoner fonksiyonun kötüleşmesi ile sonuçlanan, erken tanı ve tedavi edilmediğinde ölümcül olan bir durumdur. Biz bu yazıda miyofasiyal ağrı tedavisinde kullanılan kuru iğneleme metoduna bağlı iyatrojenik bilateral pnömotoraks gelişen ve sonra tansiyon pnömotoraksa ilerleyen olguyu sunmayı amaçladık.

Anahtar Sözcükler: Myofasial ağrı, kuru iğneleme, tansiyon pnömotorax.
Myofascial pain (MP) is a common type of pain, characterized by muscle spasms, hypersensitivity, stiffness, limitation of movement, weakness, and autonomic disorders with extremely sensitive trigger points in the connective tissue surrounding 1 or more muscles. Many methods are used to activate trigger points and loosen tight muscles. These include dry needling and acupuncture procedures, which are minimally invasive and involve the insertion of needles directly into myofascial trigger points (MTrP). Use of these methods by physical therapists and health practitioners in the treatment of MP is becoming increasingly common, as they are effective and easy to learn $(1,2)$. However, pneumothorax or hemothorax is a serious potential complication of dry needling and acupuncture techniques applied to the thoracic region that, while rare, can be fatal (2-5).

Presently described is a case of iatrogenic bilateral pneumothorax and subsequent tension pneumothorax that developed as a result of dry needling used in the treatment of MP.
'Department of Emergency Medicine, Antalya Education and Research Hospital, Antalya, Turkey

2Department of Thoracic Surgery, Antalya Education and Research Hospital, Antalya, Turkey
'Antalya Eğitim ve Araşıırma Hastanesi, Acil Tıp Bölümü, Antalya

${ }^{2}$ Antalya Eğitim ve Araştırma Hastanesi, Göğüs Cerrahisi Bölümü, Antalya

Submitted (Başvuru tarihi): 27.03.2017 Accepted (Kabul tarihi): 02.05.2017

Correspondence (iletişim): Nalan Kozacı, Department of Emergency Medicine, Antalya Education and Research Hospital, Antalya, Turkey

e-mail: nalankozaci@gmail.com 


\section{CASE}

A 36-year-old female was transferred to our emergency department from another hospital with a history of sudden shortness of breath ongoing and worsening for 2 hours. On admission, the patient's general health condition was poor; she was confused, agitated, tachypneic, dyspneic, and orthopneic. Her vital signs were as follows: blood pressure: 90/60 mmHg, pulse: 130 beats/minute, temperature: $36^{\circ} \mathrm{C}$, respiratory rate: $55 /$ minute and oxygen saturation: $86 \%$ (under (10 L/minute oxygen therapy). There were no breath sounds in the lungs. Heart sounds could be heard better on the right side of the chest, and were rhythmic and tachycardic. Chest radiograph revealed total pneumothorax in the left and subtotal pneumothorax in the right (Figure 1). The patient underwent bilateral tube thoracostomy (in the 5th intercostal space with a 28- $\mathrm{F}$ tube) performed by an emergency physician, starting from the left side. The patient's respiratory distress improved dramatically following surgical intervention and both lungs were seen to be expanded on chest radiograph (Figure 2). The patient was taken to service on postoperative day 1 after being hospitalized in the intensive care unit for follow-up. The detailed history taken from the patient revealed that she had undergone dry needling for pain in her neck and back muscles (between the spinous processes and scapulae). She experienced shortness of breath about 2 hours after the procedure with worsening onset. The patient's drains were removed on postoperative days 3 and 4 . The patient was discharged on postoperative day 5 with bilaterally expanded lungs observed on chest radiograph.

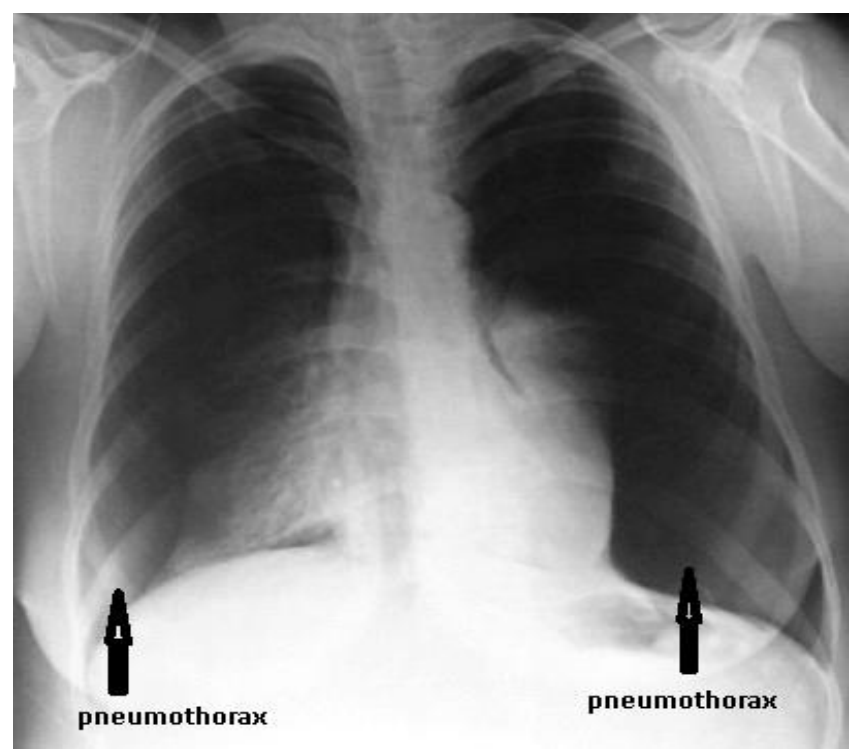

Figure 1: Chest radiograph revealed total pneumothorax in the left and subtotal pneumothorax in the right

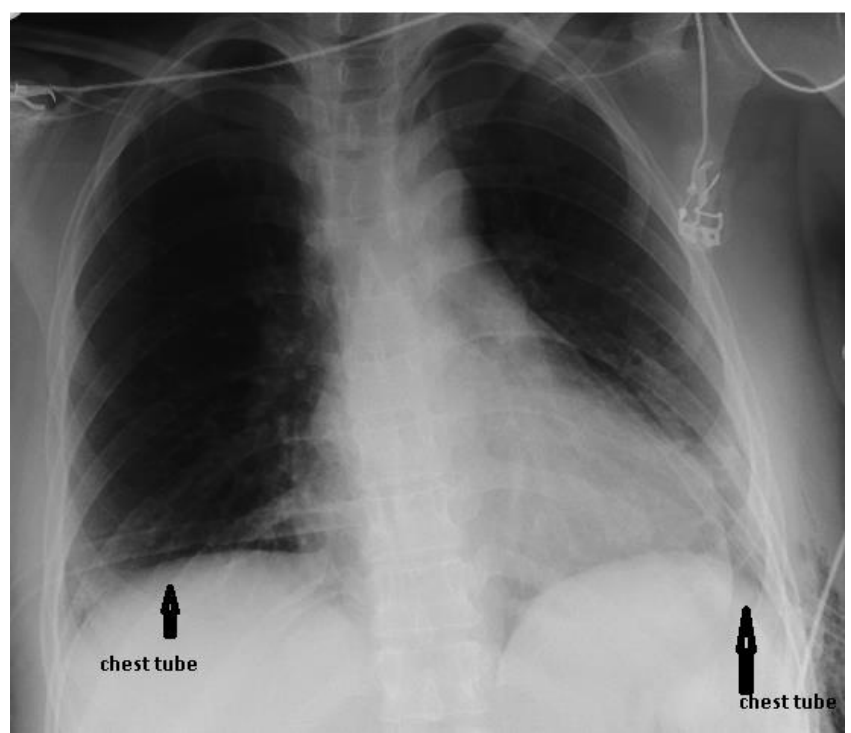

Figure 2: The patient underwent bilateral tube thoracostomy

\section{DISCUSSION}

MP is a common syndrome seen by practitioners worldwide. It can affect up to $10 \%$ of the adult population and can account for acute and chronic pain complaints. MP arises from muscles or the related fascia, and is usually associated with MTrP. Numerous noninvasive methods, such as stretching, massage, ischemic compression, laser therapy, heat, acupressure, ultrasound, transcutaneous electrical nerve stimulation, biofeedback, and pharmacological treatments, are used to alleviate chronic MP. Another way to treat MP is dry needling, which is a minimally invasive procedure in which an acupuncture needle is inserted directly into an MTrP. The sites for needle insertion are located in the skeletal muscles taught in any basic anatomy course. Dry needling is a basic course, usually lasting 2 to 4 days and easy to learn. (1)

In systematic reviews and clinical guidelines, dry needling and acupuncture have been reported to be useful in treating a variety of musculoskeletal diseases, including cervical spine pain, low back pain, pelvic girdle pain, and tension-type headache $(6,7)$.

Dry needling can be applied superficially or deeply. Several studies have compared superficial to deep dry needling. But the authors found no statistical difference between the 2 methods. (1)

Several adverse effects associated specifically with dry needling have been reported. These include soreness after needling, local hemorrhage at the needling site, asyncopal responses, and pneumothorax (1-5).

Pneumothorax is a well-recognized but rare adverse event related to acupuncture or deep dry needling over the thorax. The largest prospective survey of adverse events of 
acupuncture found 2 cases of pneumothorax related to 2.2 million acupuncture sessions in 0.22 million patients, but we do not know what proportion of the 2.2 million treatments surveyed involved needling over the thorax. (2) latrogenic pneumothorax is more frequent when dry needling is applied to the upper trapezius, thoracic erector spinae, and rhomboid muscles. Other regions in the chest area with pneumothorax risk are the subclavicular region, supraclavicular region, intercostal spaces, interspinal spaces and congenital foramen associated with the sternum, and the suprascapular and infrascapular fossa $(3,8)$. In 1 of the reported cases, needling was applied to the paravertebral point in the spinous process of the third vertebra, and in the other, between the spinous process and the scapula $(4,5)$. Similarly, in our case, needling was performed on the back muscles between the spinous processes and the scapula. Therefore, physiotherapists and medical practitioners must be careful during the needling of thoracic area to minimize the possibility of accidental pneumothorax. It is also very important that practitioners can recognize pneumothorax (8).

latrogenic pneumothorax due to needling usually does not occur until the completion of the treatment session. Sometimes it may develop after several hours (8). The findings of pneumothorax due to dry needling in the present case emerged 2 hours after the end of the treatment. Therefore, it is important that patients be warned of the signs and advised what to do if symptoms develop.

Signs and symptoms of pneumothorax are dyspnea, tachypnea, chest pain, dry cough, cyanosis, and the absence or reduction of respiratory sounds on auscultation in the affected area. Tension pneumothorax, which is often encountered in prehospital areas, the emergency room, or the intensive care unit, is a rare but fatal condition without early diagnosis and treatment $(9,10)$. Tension pneumothorax results in deterioration of cardiopulmonary function due to displacement of the mediastinal structures. Chest pain, dyspnea, respiratory distress, hypoxia, tachypnea, tachycardia, hypotension, jugular venous distension, contralateral tracheal deviation, respiratory and cardiac arrest occur in these patients (8-10). In our case, tracheal deviation and the displacement of mediastinal structures were not apparent. This may be due to the fact that it was an instance of bilateral pneumothorax. However, findings of tachypnea, tachycardia, hypotension, and hypoxia indicating pneumothorax were present in our patient. Waiting for a chest X-ray to confirm tension pneumothorax is associated with increased mortality. Therefore, many authors suggest immediate thoracic decompression with needle or tube thoracostomy in clinically suspected tension pneumothorax (11). In such a case, knowledge of the clinical signs of tension pneumothorax, ability to diagnose it early, and to perform emergency thoracic decompression in prehospital area, emergency room and intensive care staff is necessary for survival.

\section{CONCLUSION}

Although the dry needling method used in the treatment of MP is easy to learn and applicable, it can lead to lifethreatening complications. It is imperative that practitioners be both careful and experienced in thoracic application. They must be aware of potential complications and be able to recognize them, should they occur. In addition, patients should be informed about possible complications. For all of these reasons, we believe that practitioners should have more rigorous training.

\section{CONFLICTS OF INTEREST}

None declared.

\section{AUTHOR CONTRIBUTIONS}

Concept - N.K., N.Ç.Y., M.Ö., V.K., A.Ç.; Planning and Design - N.K., N.Ç.Y., M.Ö., V.K., A.Ç.; Supervision N.K., N.Ç.Y., M.Ö., V.K., A.Ç.; Funding - N.K., N.Ç.Y.; Materials - N.K., M.Ö.; Data Collection and/or Processing - N.K., V.K.; Analysis and/or Interpretation - N.K., A.Ç.; Literature Review - N.K., A.Ç.; Writing - N.K., N.Ç.Y.; Critical Review - N.K., M.Ö.

\section{YAZAR KATKILARI}

Fikir - N.K., N.Ç.Y., M.Ö., V.K., A.Ç.; Tasarım ve Dizayn - N.K., N.Ç.Y., M.Ö., V.K., A.Ç.; Denetleme - N.K., N.Ç.Y., M.Ö., V.K., A.Ç.; Kaynaklar - N.K., N.Ç.Y.; Malzemeler - N.K., M.Ö.; Veri Toplama ve/veya İşleme N.K., V.K.; Analiz ve/veya Yorum - N.K., A.Ç.; Literatür Taraması - N.K., A.Ç.; Yazıyı Yazan - N.K., N.Ç.Y.; Eleştirel İnceleme - N.K., M.Ö.

\section{REFERENCES}

1. Kalichman L, Vulfsons S. Dry needling in the management of musculoskeletal pain. J Am Board Fam Med 2010; 23:640-6. [CrossRef]

2. Cummings M, Ross-Marrs R, Gerwin R. Pneumothorax complication of deep dry needling demonstration. Acupunct Med 2014; 32:517-9. [CrossRef]

3. Karavis MY, Argyra E, Segredos V, Yiallouroy A, Giokas $G$, Theodosopoulos T. Acupuncture-induced haemotho- 
rax: a rare iatrogenic complication of acupuncture. Acupunct Med 2015; 33:237-41. [CrossRef]

4. Su JW, Lim CH, Chua YL. Bilateral pneumothoraces as a complication of acupuncture. Singapore Med J 2007;48:e32-3.

5. Lee WM, Leung HB, Wong WC. latrogenic bilateral pneumothorax arising from acupuncture: a case report J Orthop Surg (Hong Kong) 2005; 13:300-2. [CrossRef]

6. Kietrys DM, Palombaro KM, Mannheimer JS. Dry needling for management of pain in the upper quarter and craniofacial region. Curr Pain Headache Rep 2014; 18:437. [CrossRef]

7. Liu L, Huang QM, Liu QG, Ye G, Bo CZ, Chen MJ, et al. Effectiveness of dry needling for myofascial trigger points associated with neck and shoulder pain: a systematic review and meta-analysis. Arch Phys Med Rehabil 2015; 96:944-55. [CrossRef]
8. McCutcheon L, Yelland M. latrogenic pneumothorax: safety concerns when using acupuncture or dry needling in the thoracic region. J Physical Therapy Rev 2011; 16:126-32. [CrossRef]

9. Roberts DJ, Leigh-Smith S, Faris PD, Blackmore C, Ball $\mathrm{CG}$, Robertson $\mathrm{HL}$, et al. Clinical presentation of patients with tension pneumothorax: a systematic review. Ann Surg 2015; 261:1068-78. [CrossRef]

10. Roberts DJ, Leigh-Smith S, Faris PD, Ball CG, Robertson $\mathrm{HL}$, Blackmore $\mathrm{C}$, et al. Clinical manifestations of tension pneumothorax: protocol for a systematic review and meta-analysis. Syst Rev 2014; 4;3:3. [CrossRef]

11. Zarogoulidis P, Kioumis I, Pitsiou G, Porpodis K, Lampaki $S$, Papaiwannou A, et al. Pneumothorax: from definition to diagnosis and treatment. J Thorac Dis 2014; 6:S3726. [CrossRef] 